\title{
Mechanical Properties and Degradation Behaviors of Zn-xMg Alloy Fine Wires for Biomedical Applications
}

\author{
Jing Bai $\mathbb{D}^{1,2}$ Yan Xu, ${ }^{1}$ Qizhou Fan, ${ }^{1}$ Ruihua Cao, ${ }^{1}$ Xingxing Zhou, ${ }^{3}$ Zhaojun Cheng, ${ }^{1,2}$ \\ Qiangsheng Dong, ${ }^{1,2}$ and Feng Xue ${ }^{1,2}$ \\ ${ }^{1}$ Jiangsu Key Laboratory for Advanced Metallic Materials, School of Materials Science and Engineering, Southeast University, \\ Nanjing 211189, China \\ ${ }^{2}$ Institute of Medical Devices (Suzhou), Southeast University, Suzhou 215000, China \\ ${ }^{3}$ Jiangsu Key Laboratory of Advanced Structural Materials and Application Technology, School of Materials Science \\ and Engineering, Nanjing Institute of Technology, Nanjing 211167, China
}

Correspondence should be addressed to Jing Bai; baijing@seu.edu.cn and Feng Xue; xuefeng@seu.edu.cn

Received 9 June 2021; Revised 16 July 2021; Accepted 30 November 2021; Published 24 December 2021

Academic Editor: Berndt Koslowski

Copyright (C) 2021 Jing Bai et al. This is an open access article distributed under the Creative Commons Attribution License, which permits unrestricted use, distribution, and reproduction in any medium, provided the original work is properly cited.

\begin{abstract}
$\mathrm{Zn}$ and $\mathrm{Zn}$-based alloys exhibit biosafety and biodegradation, considered as candidates for biomedical implants. Zn-0.02 wt.\% Mg (Zn-0.02 Mg), Zn-0.05 wt.\% Mg (Zn-0.05 Mg), and Zn-0.2 wt.\% Mg (Zn-0.2 Mg) wires $(\Phi 0.3 \mathrm{~mm})$ were prepared for precision biomedical devices in this work. With the addition of $\mathrm{Mg}$ in $\mathrm{Zn}-\mathrm{xMg}$ alloys, the grain size decreased along with the occurrence of $\mathrm{Mg}_{2} \mathrm{Zn}_{11}$ at the grain boundaries. Hot extrusion, cold drawing, and annealing treatment were introduced to further refining the grain size. Besides, the hot extrusion and cold drawing improved the tensile strength of $\mathrm{Zn}-\mathrm{xMg}$ alloys to $240-270 \mathrm{MPa}$ while elongation also increased but remained under $10 \%$. Annealing treatment could improve the elongation of $\mathrm{Zn}$ alloys to $12 \%-28 \%$, but decrease the tensile strength. Furthermore, $\mathrm{Zn}$-xMg wires displayed an increase in degradation rate with $\mathrm{Mg}$ addition. The findings might provide a potential possibility of $\mathrm{Zn}-\mathrm{xMg}$ alloy wires for biomedical applications.
\end{abstract}

\section{Introduction}

Biomedical devices have been paid much attention since the living standard was improved during recent decades. Therefore, Mg-based, Zn-based, and Fe-based biodegradable metals (BMs) have become research hotspots owing to their acceptable mechanical properties, good biodegradability, and suitable biocompatibility for biomedical applications [1].

Fe-based alloys have higher mechanical properties similar to that of stainless-steel implants [2]. However, the degradation rates of Fe-based BMs were so slow in vivo that might hinder the bone healing process [3]. Besides, the ferromagnetism behaviors undermine the compatibility of magnetic resonance imaging (MRI) [4]. Besides, Mg-based alloys were investigated as BMs due to their excellent biocompatibility and suitable mechanical properties close to human bone $[1,2,5,6]$. Mg ions play a positive role in pro- moting osteoblast proliferation and cell viability [7]. Nevertheless, an underlying problem is that a fast degradation rate destroys the mechanical integrity of implants during the healing of tissue $[8,9]$.

To explore suitable BMs with a moderate degradation rate and biomechanical compatibility, $\mathrm{Zn}$ and $\mathrm{Zn}$ alloys were investigated for biomedical applications [10-16]. Zn elements are also necessary microelements in the human body, which participate in life activities as major ingredients for vast macromolecules and enzymes in biomembrane formation $[17,18]$. Besides, $\mathrm{Zn}$ has a standard electrode potential (vs standard hydrogen electrode) $(-0.7618 \mathrm{~V})$ between that of $\mathrm{Mg}(-2.372 \mathrm{~V})$ and $\mathrm{Fe}(-0.447 \mathrm{~V})$ [19], indicating a moderate degradation rate of $\mathrm{Zn}$ as BMs. Bowen et al. [20] studied pure $\mathrm{Zn}$ wires implanted in the artery of rats for 6 months and found that pure $\mathrm{Zn}$ wires had a proper degradation rate and favorable biocompatibility. However, the as-cast pure $\mathrm{Zn}$ has been reported limited elongation and tensile strength 
TABLE 1: Chemical composition analyzed by OES.

\begin{tabular}{lccccccccc}
\hline \multirow{2}{*}{ Materials } & & & \multicolumn{3}{c}{ Composition (wt.\%) } & & $\mathrm{Mn}$ & $\mathrm{Ni}$ & $\mathrm{Zn}$ \\
& $\mathrm{Mg}$ & $\mathrm{Al}$ & $\mathrm{Cu}$ & $\mathrm{Pb}$ & $\mathrm{Sn}$ & $\mathrm{Fe}$ & 0.0009 & Balance \\
\hline Zn & 0.0012 & 0.0120 & 0.0013 & 0.0092 & 0.0064 & 0.0075 & 0.0010 & 0.0009 \\
Zn-0.02 mg & 0.0223 & 0.0018 & 0.0014 & 0.0100 & 0.0110 & 0.0070 & 0.0025 & 0.0017 & Balance \\
Zn-0.05 mg & 0.0488 & 0.0013 & 0.0013 & 0.0105 & 0.0127 & 0.0083 & 0.0027 & 0.0020 & Balance \\
Zn-0.2 mg & 0.193 & 0.0013 & 0.0014 & 0.0103 & 0.0142 & 0.0090 & 0.0043 & 0.0021 & Balance \\
\hline
\end{tabular}

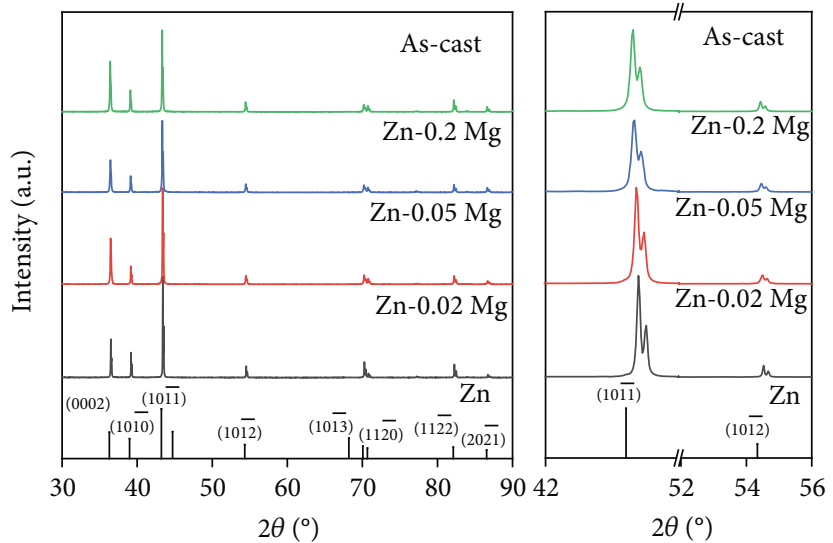

(a)

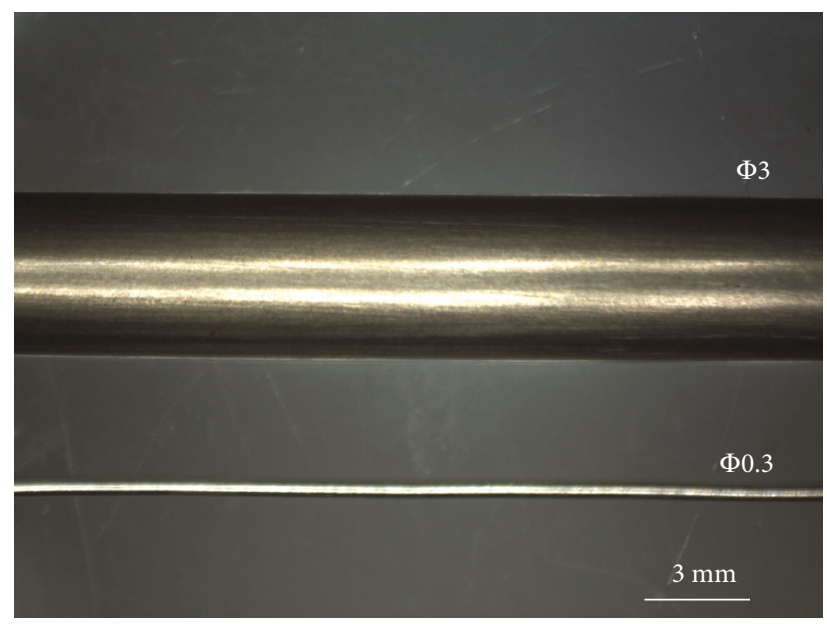

(c)

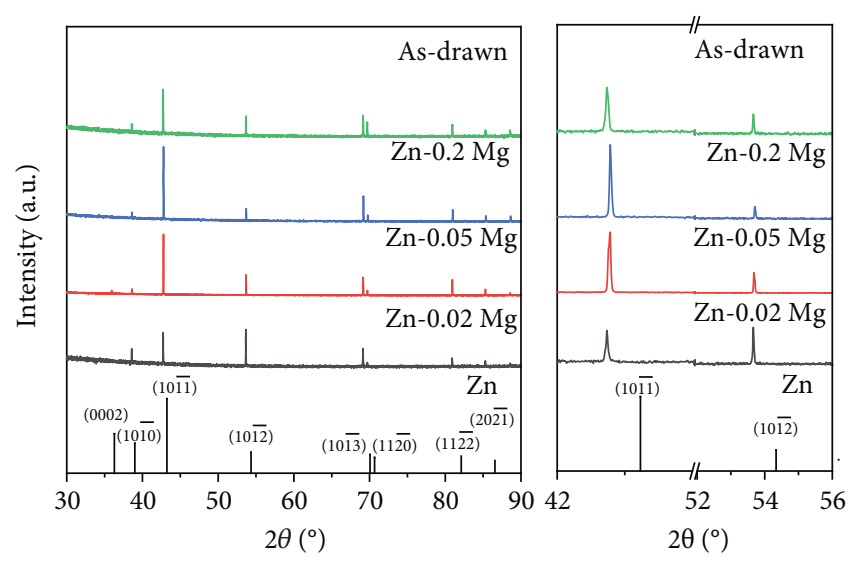

(b)

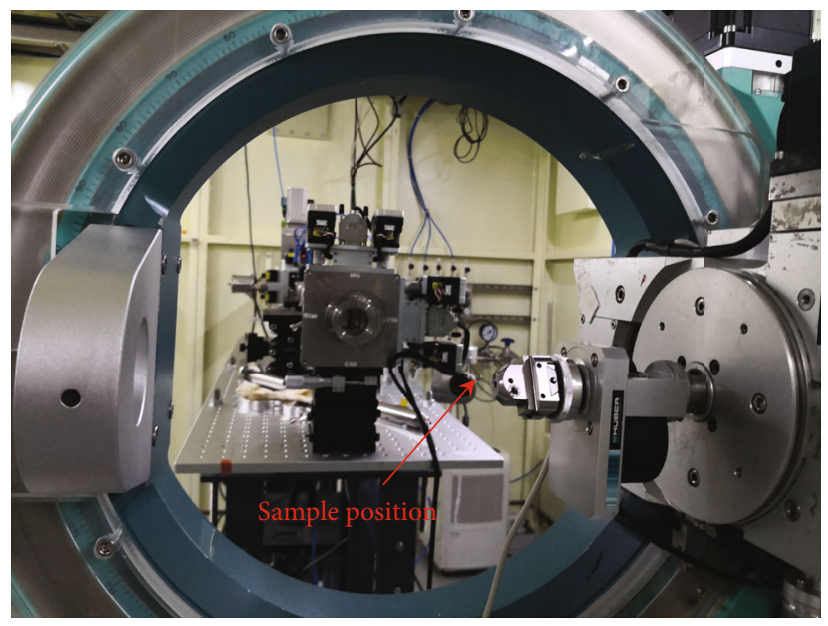

(d)

FIGURE 1: (a) XRD pattern of as-cast Zn-xMg alloys, (b) SR-XRD pattern of cold-drawn alloy wires, (c) optical morphology of alloy wires with $0.3 \mathrm{~mm}$ and $3 \mathrm{~mm}$ in diameter, and (d) synchronous radiator.

[21]. The drawbacks on undesirable plasticity and strength would be worthy of solving to expand clinical applications. The common metal materials are strengthened and plasticized through alloying and deformation combined with proper thermal treatment. Li et al. [22] reported that the mechanical properties of $\mathrm{Zn}$ alloys were improved by $\mathrm{Mg}$, $\mathrm{Ca}$, and $\mathrm{Sr}$ alloying and deformation process, resulting in that the ultimate tensile strength and elongation reached about $250 \mathrm{MPa}$ and $7 \%$, respectively. $\mathrm{Zn}-\mathrm{Mg}$ alloys are widely studied among biodegradable $\mathrm{Zn}$ alloys [2]. Also, our research group prepared $\mathrm{Zn}-1.6 \% \mathrm{Mg}$ alloy via multipass equal channel angular pressing and the optimal mechanical properties with the ultimate tensile strength of $423 \mathrm{MPa}$, the yield strength of $361 \mathrm{MPa}$, and the elongation of $5.2 \%$ [14]. In addition, $\mathrm{Zn}-\mathrm{Mg}$ alloys have been reported good biocompatibility and osteogenesis in vivo and in vitro [22-24]. Therefore, $\mathrm{Zn}-\mathrm{Mg}$ alloys are worthy of further investigation to explore wide biomedical applications.

Recently, BM wires have been paid much attention as temporary medical devices. Herein, BM sutures are potential biomedical applications owing to broadly accepted biodegradability, biocompatibility, and mechanical properties [25]. Our research group developed $\mathrm{Mg}$ alloy fine wire with a diameter of less than $0.4 \mathrm{~mm}$ [26]. Guo et al. [27] reported pure $\mathrm{Zn}$ wire for suture application. $\mathrm{Zn}-\mathrm{Mg}$ alloys with a diameter of $0.6 \mathrm{~mm}$ have been developed for urinary tract 


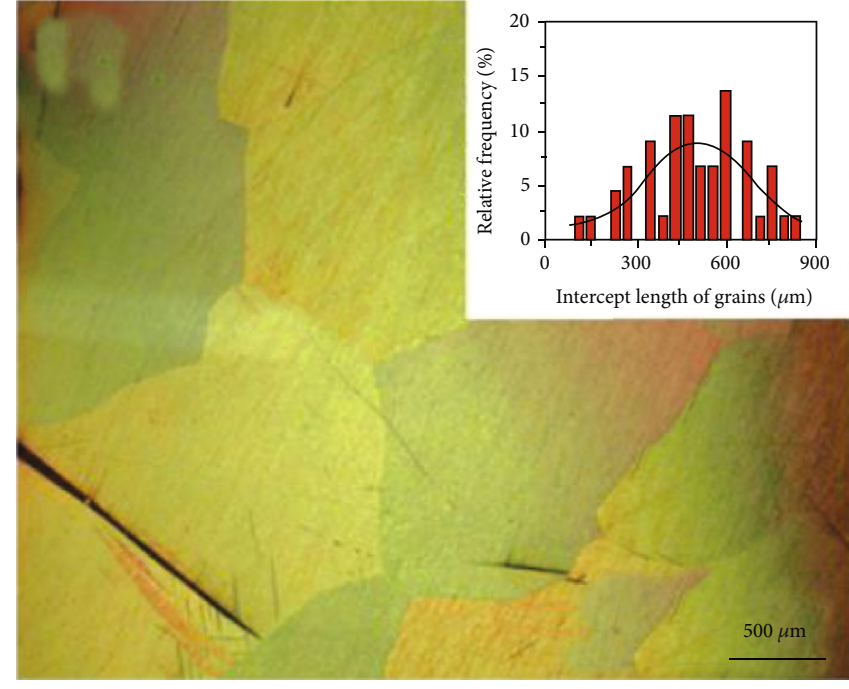

(a)

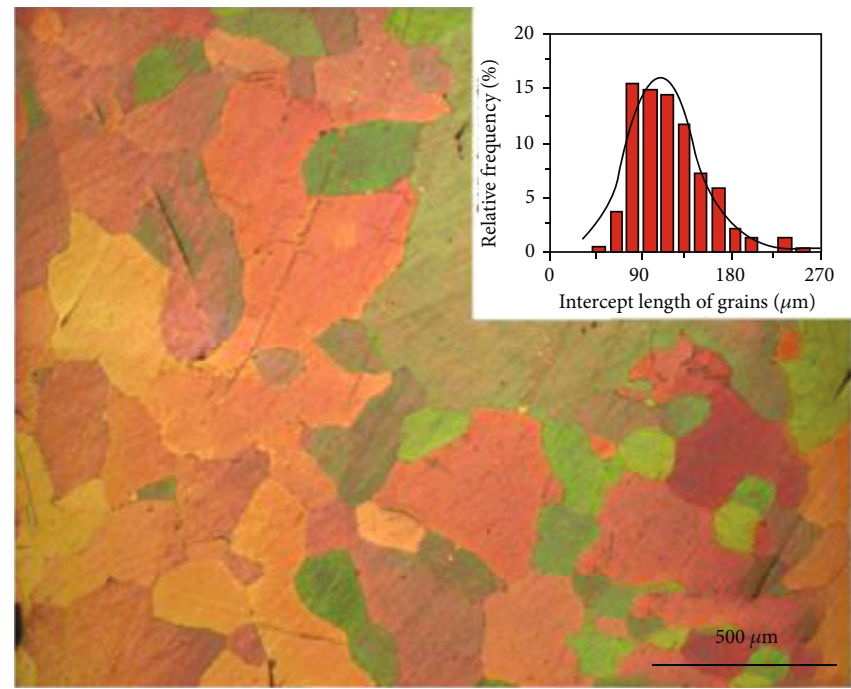

(c)

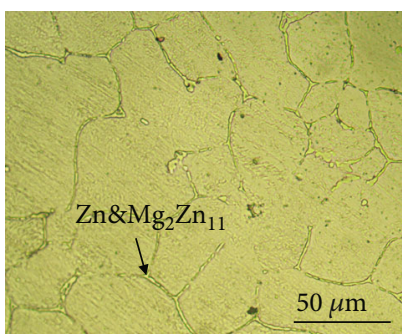

(e)

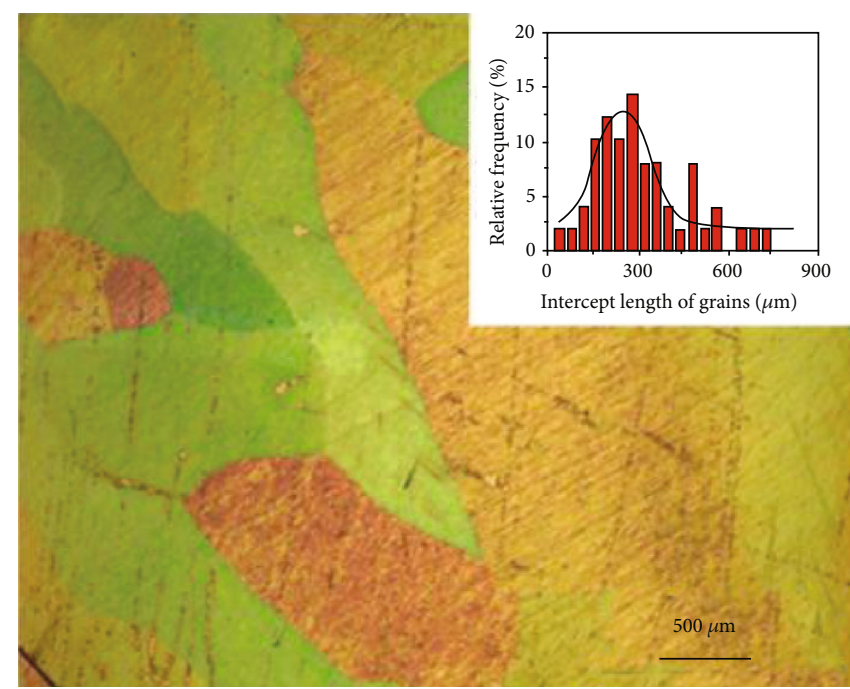

(b)

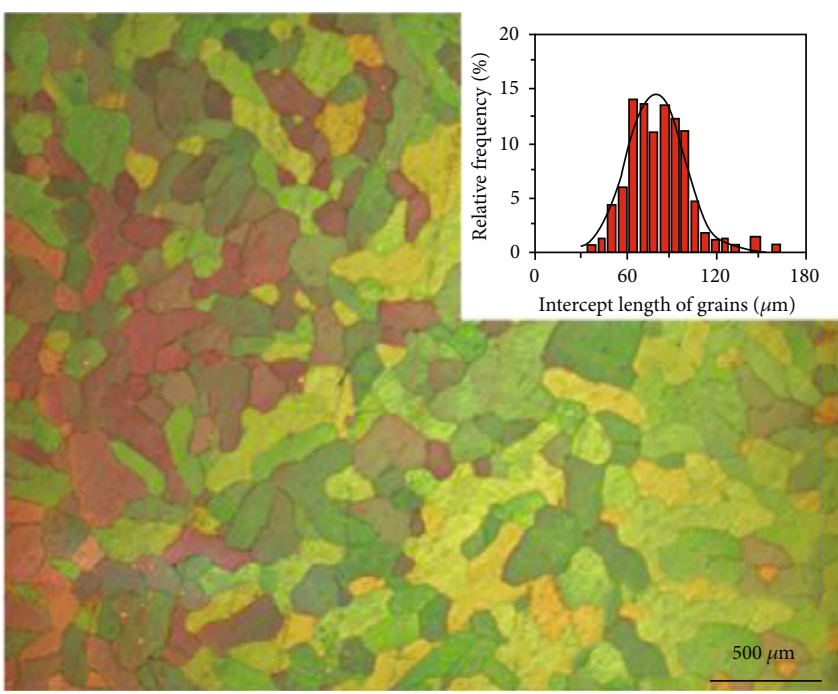

(d)

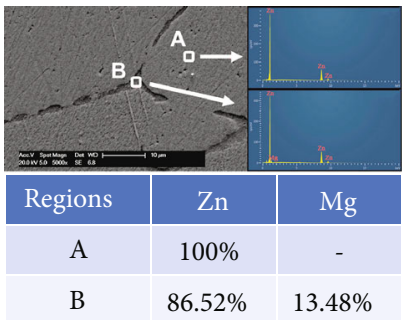

(f)

Figure 2: Microstructures of as-cast pure Zn (a), Zn-0.02 Mg (b), Zn-0.05 Mg (c) and Zn-0.2 Mg (d,e), and SEM and EDS for Zn-0.2 Mg (f).

surgeries [28]. BM fine wire with a diameter of less than $0.5 \mathrm{~mm}$ showed huge potentials in medical applications [26]. Zn alloy wires are appropriate for high strength sutures in hard tissue applications, which are required to have a long lifetime degradation of up to 2 years [25]. Furthermore, to explore precision medical implants with service performances, $\mathrm{Zn}-\mathrm{xMg}$ ( $x=0.02$ wt.\%, 0.05 wt.\%, 0.2 wt.\%) alloy fine wires $(\Phi 0.3 \mathrm{~mm})$ were developed via hot extrusion, cold drawing, and annealing treatment. The microstructures and mechanical properties of different alloys through the whole process were analyzed and studied in detail. Besides, in vitro corrosion experiments were introduced to evaluate the corrosion properties of $\mathrm{Zn}-\mathrm{xMg}$ alloy wires.

\section{Materials and Methods}

2.1. Material Preparation. The nutrient element $\mathrm{Mg}$ was selected as an alloying element for $\mathrm{Zn}-\mathrm{xMg}$ alloys, 


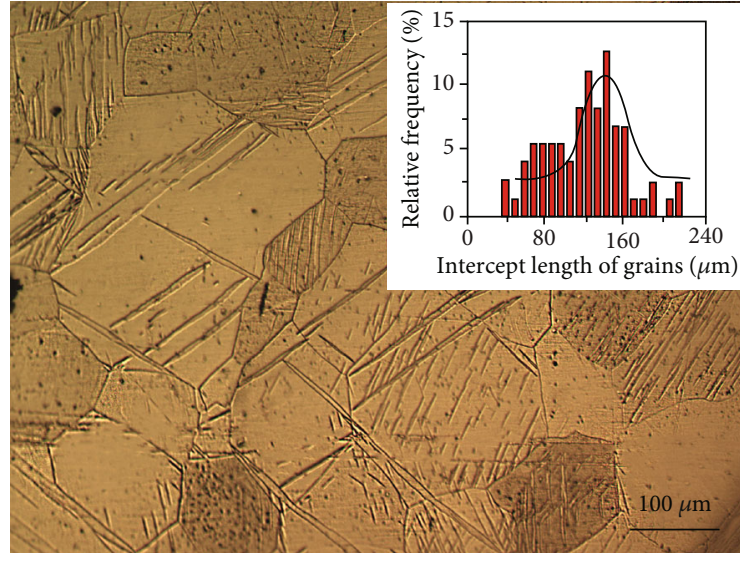

(a)

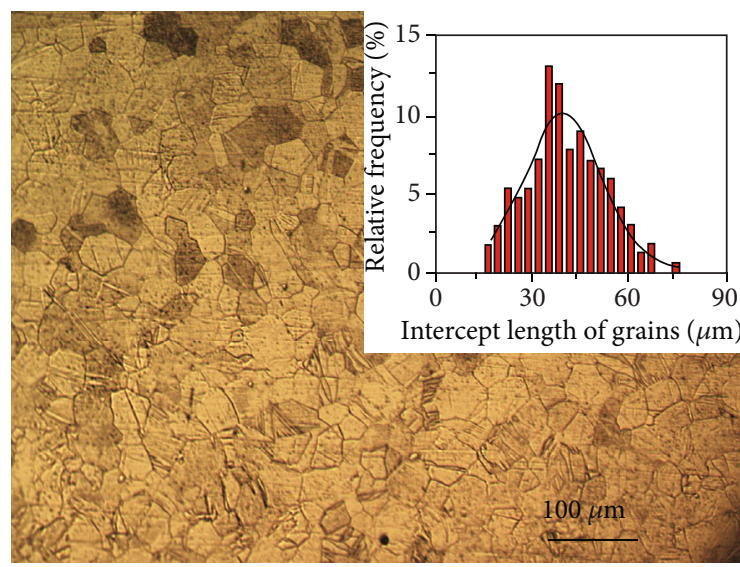

(c)

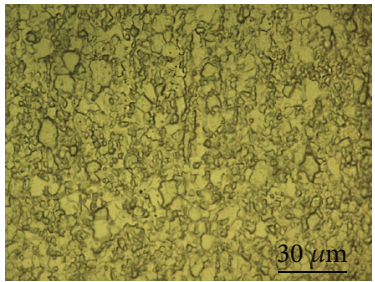

(e)

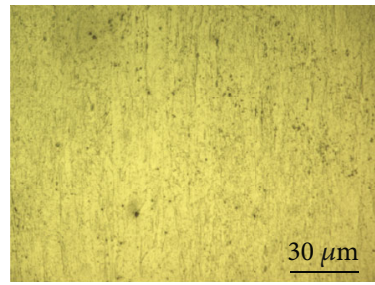

(f)

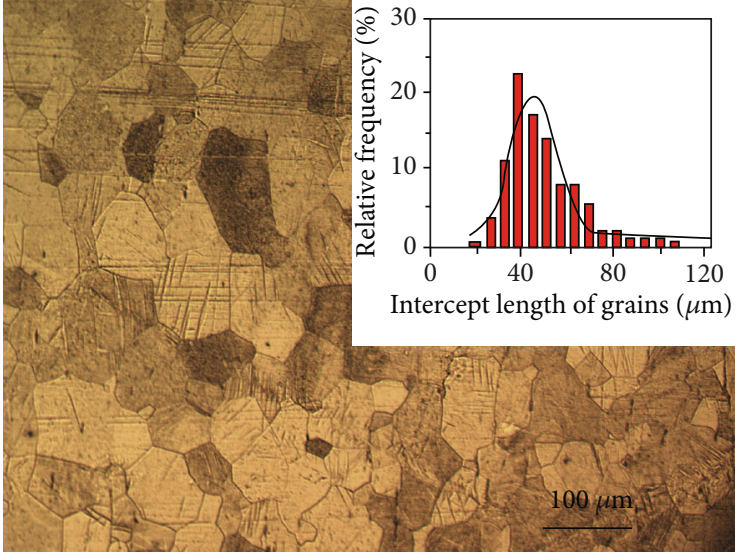

(b)

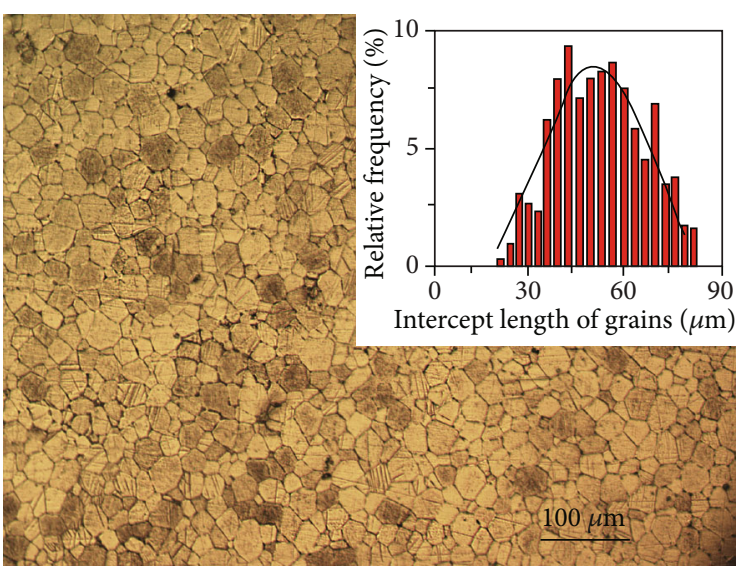

(d)

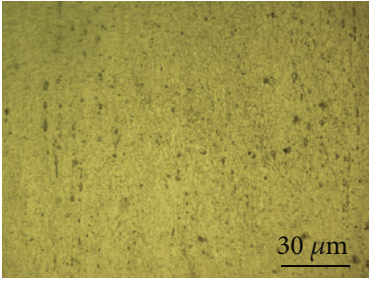

(g)

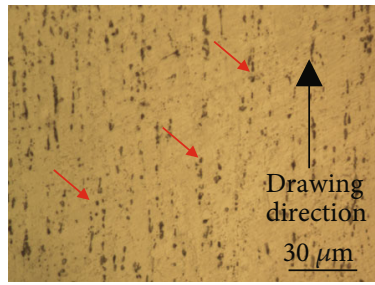

(h)

Figure 3: Microstructures of as-extruded $\mathrm{Zn}$ and $\mathrm{Zn}-\mathrm{xMg}$ alloys: (a) Zn, (b) Zn-0.02 Mg, (c) Zn-0.05 Mg, and (d) Zn-0.2 Mg; microstructures of as-drawn $\mathrm{Zn}$ and $\mathrm{Zn}-\mathrm{xMg}$ alloys: (e) $\mathrm{Zn}$, (f) Zn-0.02 Mg, (g) Zn-0.05 Mg, and (h) Zn-0.2 Mg.

including $\mathrm{Zn}-0.02$ wt\% $\mathrm{Mg}(\mathrm{Zn}-0.02 \mathrm{Mg}), \mathrm{Zn}-0.05$ wt $\% \mathrm{Mg}$ $(\mathrm{Zn}-0.05 \mathrm{Mg})$, and $\mathrm{Zn}-0.2 \mathrm{wt} \% \mathrm{Mg}(\mathrm{Zn}-0.2 \mathrm{Mg})$. Pure $\mathrm{Zn}$ and $\mathrm{Zn}-\mathrm{xMg}$ alloys were prepared by melting pure $\mathrm{Zn}$ (99.95\%) and pure $\mathrm{Mg}$ (99.95\%) in an iron crucible shielded by mixed gas $\left(\mathrm{CO}_{2}\right.$ and $\left.\mathrm{SF}_{6}\right)$ using a resistance furnace. The molten metal was cast into a water-cooled cylindrical coppery mold $(\Phi 60 \mathrm{~mm}$ ) to obtain the as-cast $\mathrm{Zn}$ alloy ingots.

$\mathrm{Zn}-\mathrm{xMg}$ alloy ingots were annealed at $350^{\circ} \mathrm{C}$ for $24 \mathrm{~h}$ to acquire uniform microstructures and then hot extruded at $200-300^{\circ} \mathrm{C}$ and an extrusion rate of $25: 1$. Next, the hotextruded $\mathrm{Zn}-\mathrm{xMg}$ alloy wires with a diameter of $\Phi 3 \mathrm{~mm}$ were cold-drawn to $\Phi 0.3 \mathrm{~mm}$ by a self-made drawing machine at room temperature (RT) [27]. If broken during cold drawing, the $\mathrm{Zn}-\mathrm{xMg}$ alloys were annealed at $200^{\circ} \mathrm{C}$ for $5 \mathrm{~min}$. Finally, $\mathrm{Zn}$ alloy wires $(\Phi 0.3 \mathrm{~mm})$ were annealed at different temper- atures $\left(100^{\circ} \mathrm{C}, 150^{\circ} \mathrm{C}, 200^{\circ} \mathrm{C}, 250^{\circ} \mathrm{C}, 300^{\circ} \mathrm{C}\right)$ for different times (10 $\mathrm{min}, 30 \mathrm{~min}$ ) to enhance the plasticity.

2.2. Microstructure Characterization. The metallographic microstructure paralleled to the deforming direction was detected and collected using an optical microscope (Olympus, Shinjuku, Tokyo, Japan). Before observation, the samples were ground and polished to mirror surface and then etched by a mixed solution of $\mathrm{CrO}_{3}$ and $\mathrm{Na}_{2} \mathrm{SO}_{4}\left(10 \mathrm{~g} \mathrm{CrO}_{3}, 0.75 \mathrm{~g}\right.$ $\mathrm{Na}_{2} \mathrm{SO}_{4}$, and $50 \mathrm{~mL} \mathrm{H}_{2} \mathrm{O}$ ) for 6-7 s at RT. The grain size was measured by the linear intercept technique [29]. Besides, the phases of the as-cast alloy were analyzed by an X-ray diffractometer (XRD, D8-Discover, German Bruker). The microstructures of cold-drawn alloy wires $(\Phi 0.3 \mathrm{~mm})$ were characterized by synchrotron radiation X-ray diffractometer 


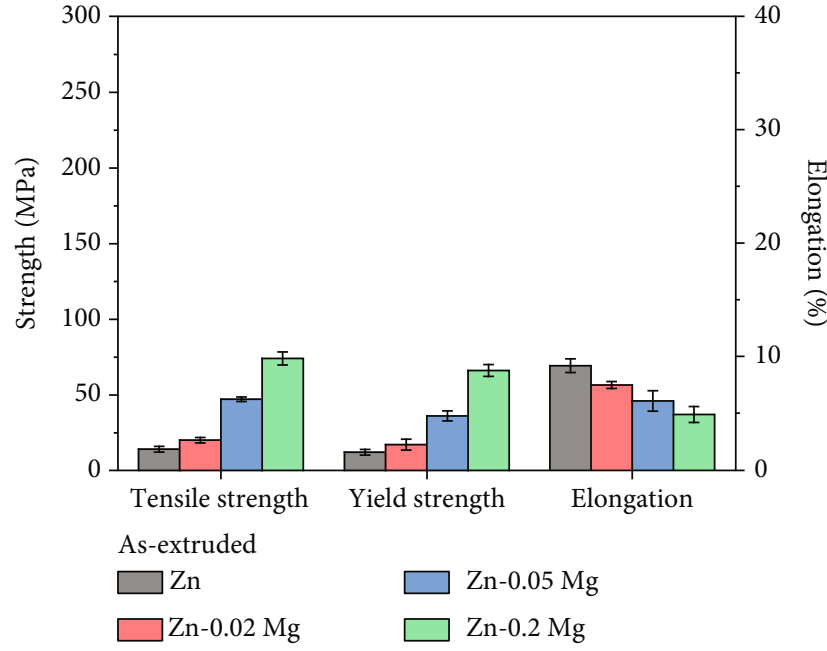

(a)

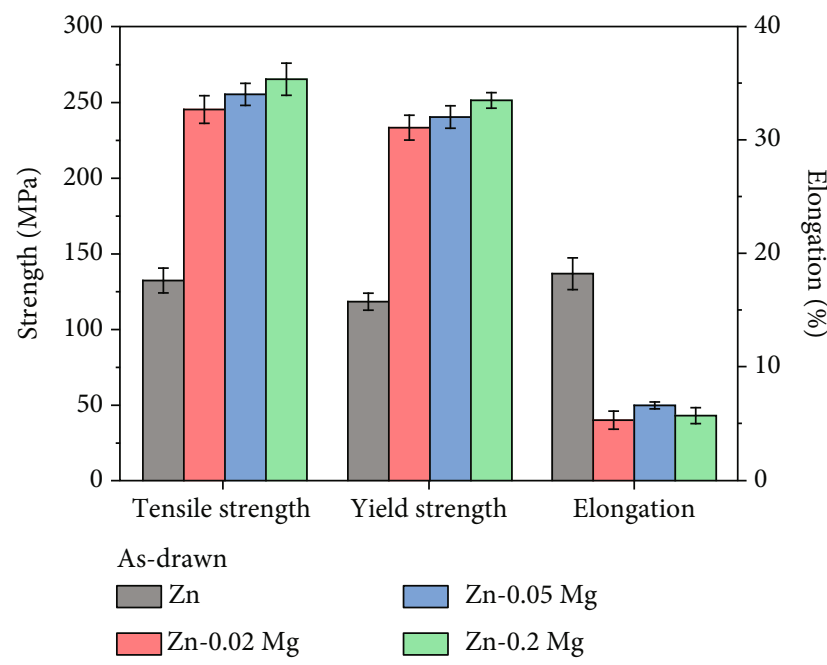

(c)

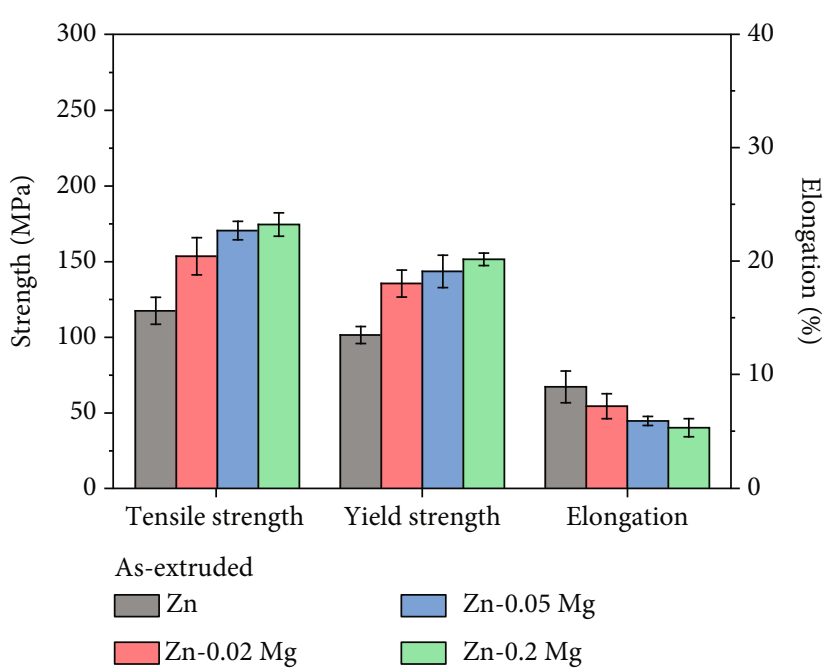

(b)

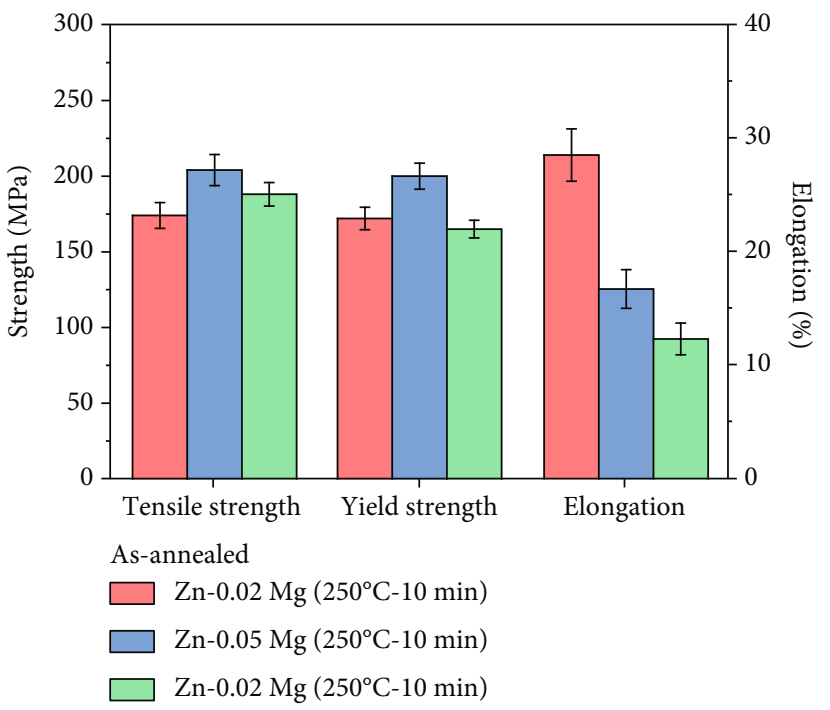

(d)

Figure 4: Mechanical properties of pure $\mathrm{Zn}$ and $\mathrm{Zn}-\mathrm{xMg}$ alloys in different states: (a) as-cast, (b) as-extrude, (c) as-drawn, and (d) asannealed.

(SR-XRD) at BL14B1 station, SSRF (Shanghai, China). Moreover, the second phases in $\mathrm{Zn}-\mathrm{Mg}$ alloys were identified by a scanning electron microscope (SEM, Sirion 200) equipped with an energy dispersive spectrometer (EDS).

2.3. Mechanical Properties. Mechanical properties, including ultimate tensile strength (UTS), yield strength (YS), and elongation to fracture (EL), were measured by a universal material test machine (CTM4503). The wires with a gauge size of $50 \mathrm{~mm}$ in the center and a clamping size of $20 \mathrm{~mm}$ at both ends were designed as tensile samples. The mechanical tests for each sample were repeated three times at a constant tensile speed of $2 \mathrm{~mm} / \mathrm{min}$ at RT.

The microhardness of the $\mathrm{Zn}$ alloy wires was measured using a microhardness tester (FM-700, Future-Tech, Japan) with a loading force of 100 gf. The hardness values of $\mathrm{Zn}$ alloy wires were collected and analyzed based on ten testing points of each sample.
2.4. Corrosion Behaviors. Corrosion behavior was measured by electrochemical methods and immersion tests in Hank's solution at $37 \pm 0.5^{\circ} \mathrm{C}$. In these electrochemical measurements, an electrochemical station (CHI660E) was carried out to collect open circuit potential (OCP) and potentiodynamic polarization (PP) curves. A classical three-electrode cell was applied for electrochemical measurements, in which the working electrode was $\mathrm{Zn}$ alloy wires with a fixed exposed area in Hank's solution, the platinum electrode was set as a counter electrode, and a saturated calomel electrode was acted as a reference electrode. Prior to electrochemical measurements, $\mathrm{Zn}$ alloy wires were acid cleaned in $1 \%$ nitric acid solution to remove surface oxide films. The wires were inserted vertically in Hank's solution for electrochemical measurements. The immersion length of the wires was recorded to calculate the exposed surface area. OCP curves were measured for $2400 \mathrm{~s}$ in Hank's solution. PP curves were scanned from $-1.6 \mathrm{~V}$ vs SCE to $-0.6 \mathrm{~V}$ vs. SCE at 


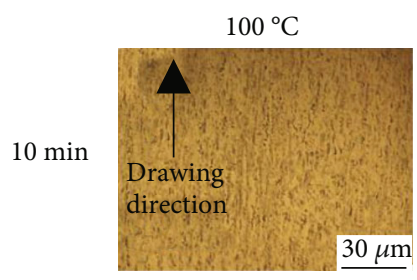

(a)

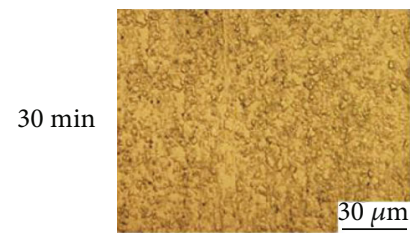

(e)

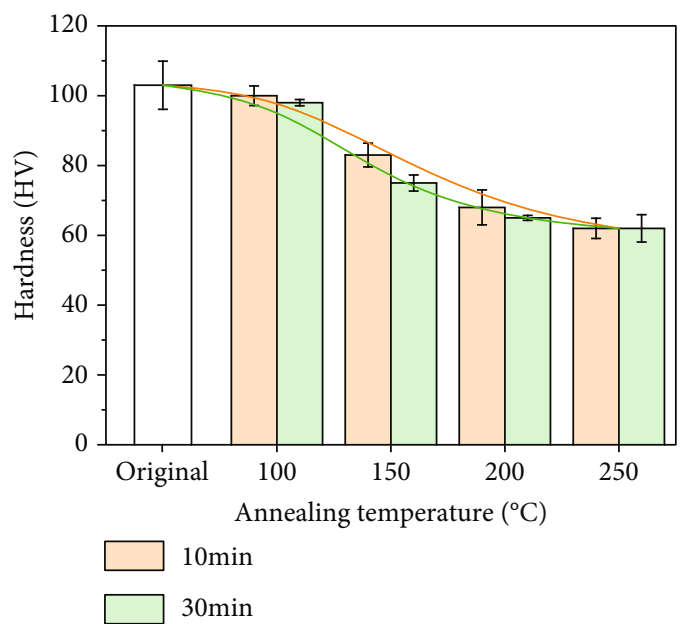

(i)

(b)

(f)
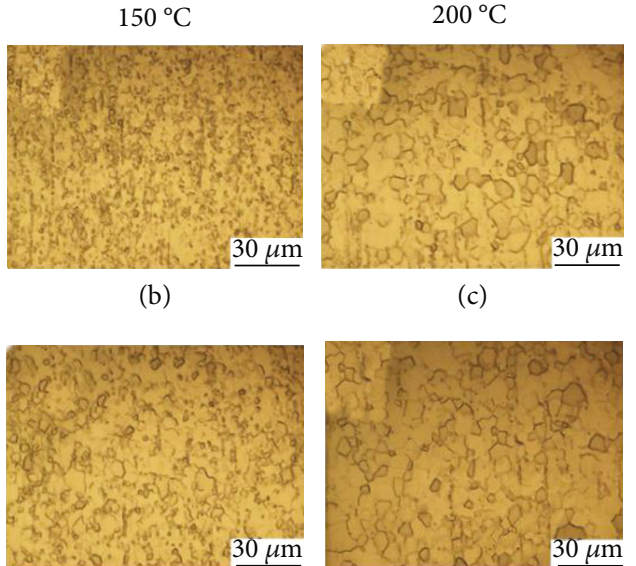

(c)

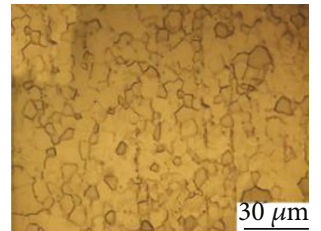

(g)

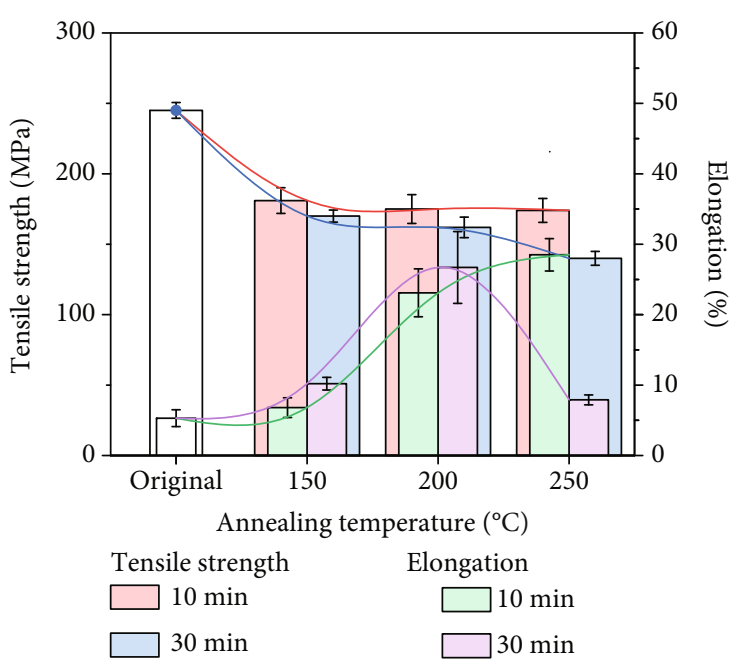

(j)

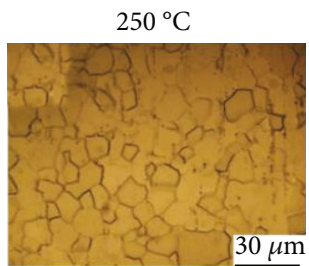

(d)

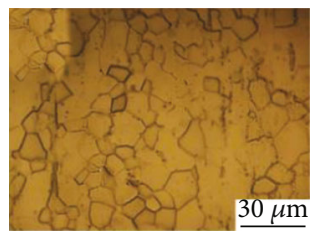

(h)

FIgure 5: Microstructures and mechanical properties of $\mathrm{Zn}-0.02 \mathrm{Mg}$ wire annealed under different conditions: (a) $100^{\circ} \mathrm{C}-10 \mathrm{~min}$, (b) $150^{\circ} \mathrm{C}$ $10 \mathrm{~min}$, (c) $200^{\circ} \mathrm{C}-10 \mathrm{~min}$, (d) $250^{\circ} \mathrm{C}-10 \mathrm{~min}$, (e) $100^{\circ} \mathrm{C}-30 \mathrm{~min}$, (f) $150^{\circ} \mathrm{C}-30 \mathrm{~min},(\mathrm{~g}) 200^{\circ} \mathrm{C}-30 \mathrm{~min}$, (h) $250^{\circ} \mathrm{C}-30 \mathrm{~min},(\mathrm{i}) \mathrm{microhardness}$, and (j) tensile strength and elongation.

a scanning rate of $1 \mathrm{mV} / \mathrm{s}$. In immersion tests, the wires were cleaned in $200 \mathrm{~g} / \mathrm{L} \mathrm{CrO}_{3}$ solution at $80^{\circ} \mathrm{C}$ for corrosion product removal and dried before and after weighting. Corrosion rate ( $\mathrm{CR}, \mathrm{mm} /$ year) was calculated referring to Equation (1) [30], where $m_{0}$ is the initial weight of specimens, $m_{1}$ is the remaining weight of specimens after corrosion, $\rho$ is the density of the alloy $\left(7.138 \mathrm{~g} / \mathrm{cm}^{3}\right.$ for $\mathrm{Zn}-0.02 \mathrm{Mg}, 7.137 \mathrm{~g} / \mathrm{cm}^{3}$ for $\mathrm{Zn}-0.05 \mathrm{Mg}$, and $7.129 \mathrm{~g} / \mathrm{cm}^{3}$ for $\mathrm{Zn}-0.2 \mathrm{Mg}$ ), and $t$ is the corrosion time. The corrosion morphology and products after $7 \mathrm{~d}$ and $14 \mathrm{~d}$ immersion were observed by SEM equipped with EDS.

$$
\mathrm{CR}=\frac{3.65 \times\left(m_{0}-m_{1}\right)}{\rho} .
$$

\section{Results and Discussion}

The chemical concentration of as-cast $\mathrm{Zn}$ and its alloys was detected by an optical emission spectrometer (OES), as exhibited in Table 1. The OES results are fitting well with the designed compositions, and a little fluctuation in chemical composition might be caused by melting loss. Figures 1(a) and 1(b) are XRD patterns of as-cast and asdrawn $\mathrm{Zn}$ alloys. The as-drawn $\mathrm{Zn}$ alloy wires were analyzed by a synchronous radiator (Figure 1(d)), in which SR-XRD was performed for phase identifying of precision devices including $\mathrm{Zn}$ alloy fine wires. The $\mathrm{Zn}$ phase (JCPDF No. 04-0831) was identified in the as-cast and as-drawn $\mathrm{Zn}$ alloys while $\mathrm{Mg}-\mathrm{Zn}$ second phase could not be found owing to the little $\mathrm{Mg}$ addition. $\mathrm{Zn}$ alloy wires with the dimension of $\Phi 3 \mathrm{~mm}$ and $\Phi 0.3 \mathrm{~mm}$ are displayed in Figure 1(c), and the surfaces show metallic color after cold drawing. Moreover, the comparison between XRD and SR-XRD patterns indicated that the texture evolution is induced by extrusion and cold drawing. There is a drastic decrease in the relative intensity of (0002) and $\left(101^{-} 0\right)$ planes, where the diffraction intensity of the $\left(101^{-} 2\right)$ plane increases in $\mathrm{Zn}-\mathrm{xMg}$ alloys. By comparison, the $\left(101^{-} 2\right)$ plane of pure $\mathrm{Zn}$ is shifted to the strongest 


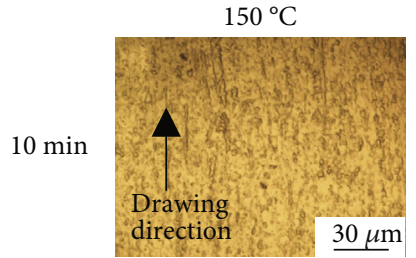

(a)

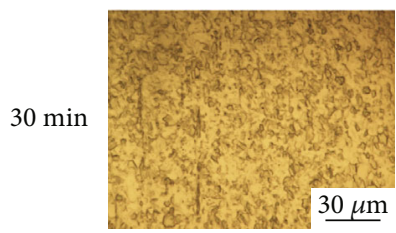

(e)

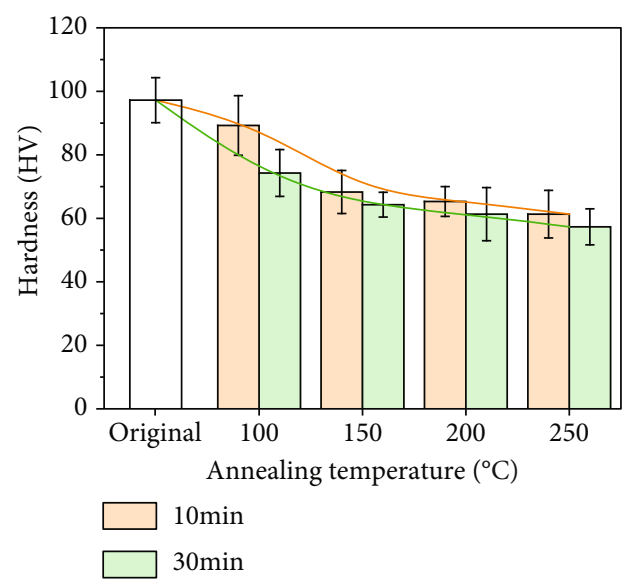

(i)

(b)

(f)
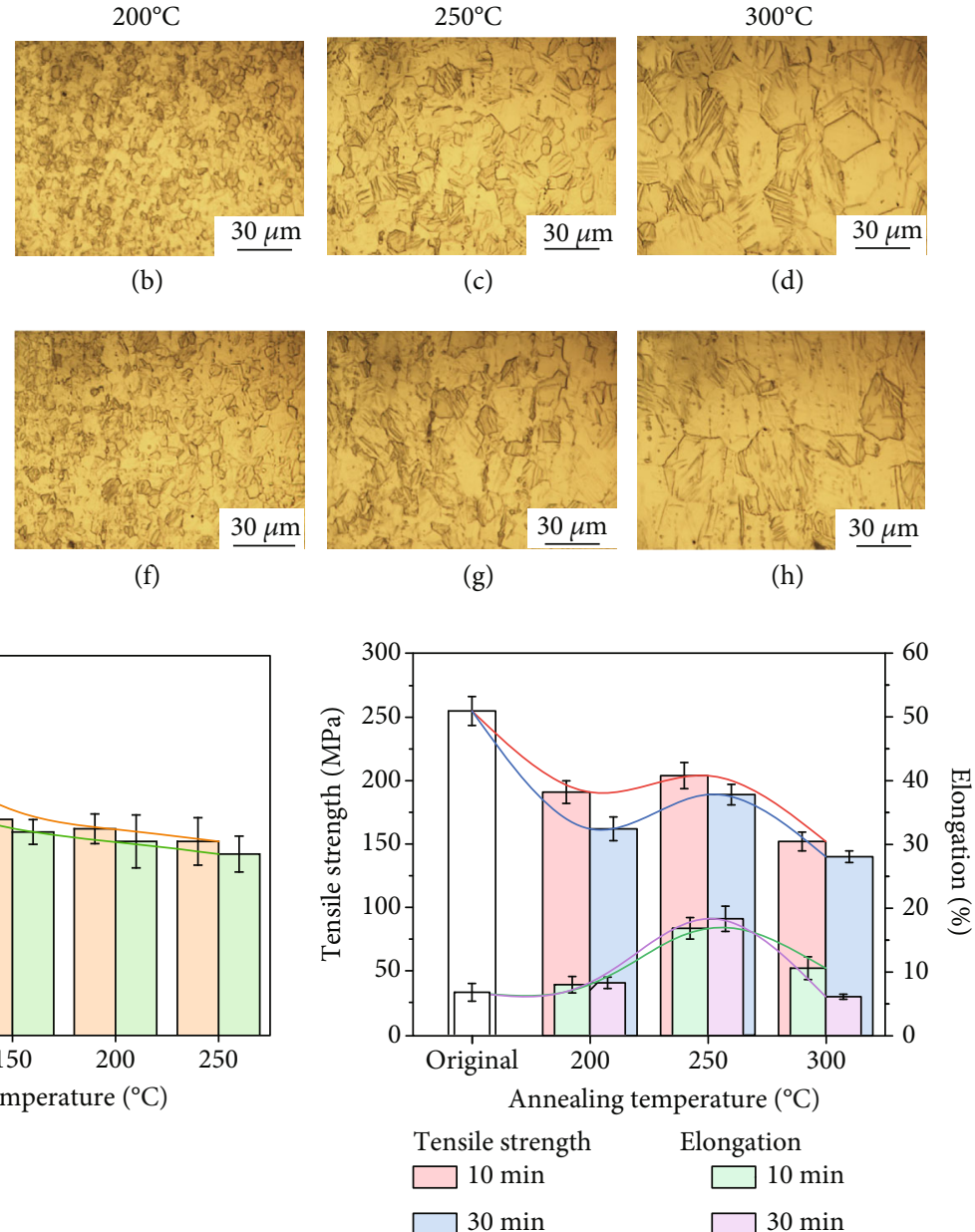

(j)

Figure 6: Microstructures and mechanical properties of $\mathrm{Zn}-0.05 \mathrm{Mg}$ wire annealed in different parameters: (a) $150^{\circ} \mathrm{C}-10 \mathrm{~min}$, (b) $200^{\circ} \mathrm{C}$ $10 \mathrm{~min}$, (c) $250^{\circ} \mathrm{C}-10 \mathrm{~min}$, (d) $300^{\circ} \mathrm{C}-10 \mathrm{~min}$, (e) $150^{\circ} \mathrm{C}-30 \mathrm{~min}$, (f) $200^{\circ} \mathrm{C}-30 \mathrm{~min}$, (g) $250^{\circ} \mathrm{C}-30 \mathrm{~min}$, (h) $300^{\circ} \mathrm{C}-30 \mathrm{~min}$, (i) microhardness, and $(\mathrm{j})$ tensile strength and elongation.

peak while $\mathrm{Zn-xMg}$ alloys still keep the $\left(101^{-} 1\right)$ plane as the strongest peak, demonstrating that the $\mathrm{Mg}$ addition hinders the $\left(101^{-} 2\right)$ plane. Also, the diffraction peaks of $\mathrm{Zn}$ and $\mathrm{Zn}-\mathrm{xMg}$ alloys are shifted to a low diffraction angle, indicating the increase of d-spacing caused by deformation. As a consequence, $\mathrm{Mg}$ alloying in $\mathrm{Zn}$ alloys induces texture evolution during deformation.

Figure 2 exhibits the microstructures of as-cast $\mathrm{Zn}$ and $\mathrm{Zn}$-xMg alloys. The average grain size of as-cast pure $\mathrm{Zn}$ is about $430 \mu \mathrm{m}$ (in Figure 2(a)). The grain sizes of $\mathrm{Zn}-\mathrm{xMg}$ alloys decrease with $\mathrm{Mg}$ addition, which are about $250 \mu \mathrm{m}$ for $\mathrm{Zn}-0.02 \mathrm{Mg}, 110 \mu \mathrm{m}$ for $\mathrm{Zn}-0.05 \mathrm{Mg}$, and $80 \mu \mathrm{m}$ for $\mathrm{Zn}$ $0.2 \mathrm{Mg}$ (in Figure 2(b)-2(d)). According to the $\mathrm{Zn}-\mathrm{Mg}$ binary phase diagram, the solubility of $\mathrm{Mg}$ in $\mathrm{Zn}$ at $\mathrm{RT}$ is $0.008 \%$, and the maximum solubility is $0.16 \%$ at $364^{\circ} \mathrm{C}$. Besides, the eutectic phases $\left(\alpha-\mathrm{Zn}+\mathrm{Mg}_{2} \mathrm{Zn}_{11}\right)$ are found with the $\mathrm{Mg}$ addition exceeding $0.15 \%$ [14]. As shown in Figure 2(e), the eutectic phases are distributed uniformly in $\mathrm{Zn}-0.2 \mathrm{Mg}$ alloys. Herein, the EDS results (in Figure 2(f)) indicated that the $\mathrm{Mg}_{2} \mathrm{Zn}_{11}$ phases are located in the grain boundary of $\mathrm{Zn}-0.2 \mathrm{Mg}$ alloys.
Figure 3 illustrates the microstructures of $\mathrm{Zn}$ and $\mathrm{Zn}$ xMg alloys after hot extrusion and cold drawing. The asextruded grains are equiaxed in shape and with smaller size. The grain size distribution graphs are analyzed as inserted in Figures 3(a)-3(d). With $\mathrm{Mg}$ addition from $0.02 \mathrm{wt} \%$ to $0.2 \mathrm{wt} \%$, the grain size and relevant distribution range are shrunk obviously. The average grain sizes of the asextruded $\mathrm{Zn}$ alloys are about $130 \mu \mathrm{m}$ for pure $\mathrm{Zn}, 60 \mu \mathrm{m}$ for $\mathrm{Zn}-0.02 \mathrm{Mg}, 40 \mu \mathrm{m}$ for $\mathrm{Zn}-0.05 \mathrm{Mg}$, and $20 \mu \mathrm{m}$ for $\mathrm{Zn}-$ $0.2 \mathrm{Mg}$, respectively. Besides, after 54 passes cold drawing without annealing, the material starts dynamic recrystallization so that the fine and equiaxed grains result see in Figure 3(e), while the original equiaxed grains of asextruded $\mathrm{Zn-xMg}$ are transformed into fibrous structures along the drawing direction. As indicated by red arrows in Figure 3(h), the intermediate phases are dispersed along the drawing direction in $\mathrm{Zn}-0.2 \mathrm{Mg}$ alloys.

Figure 4 summarizes the mechanical properties of $\mathrm{Zn}$ and $\mathrm{Zn}-\mathrm{xMg}$ alloys. In Figure 4(a), with $\mathrm{Mg}$ addition, the as-cast $\mathrm{Zn}$ and $\mathrm{Zn}$-xMg alloys appear extremely brittle with reduced ELs and improved mechanical strength including 


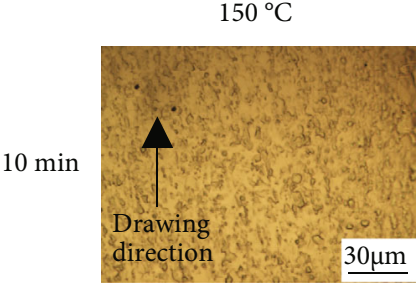

(a)

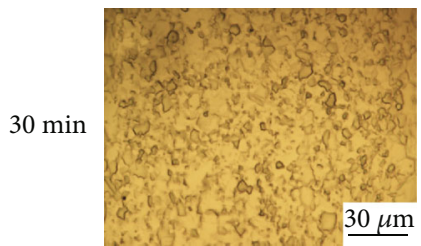

(e)

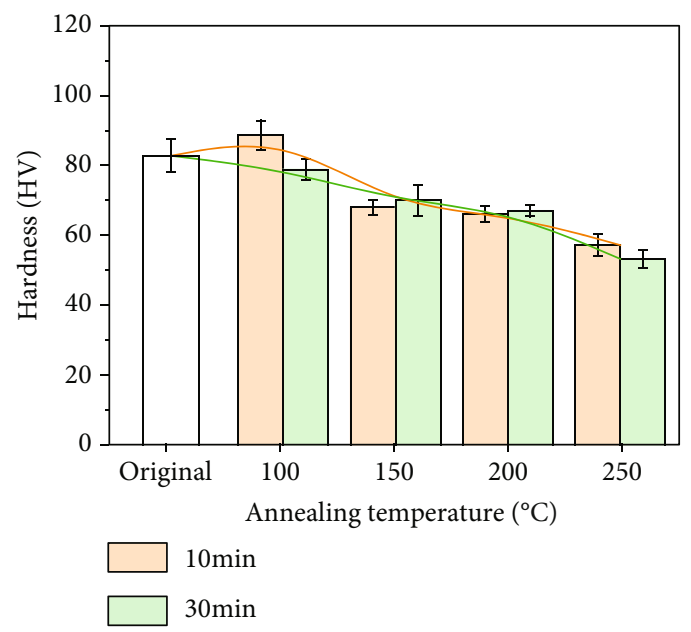

(i)

(b)

(f)
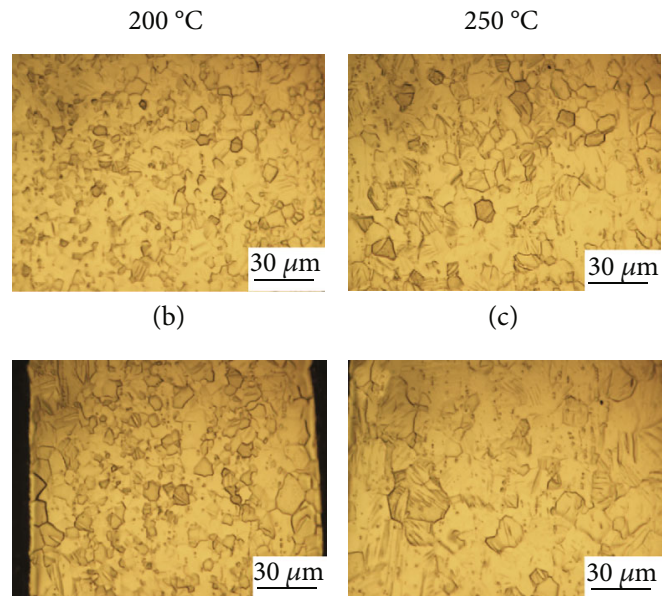

(c)

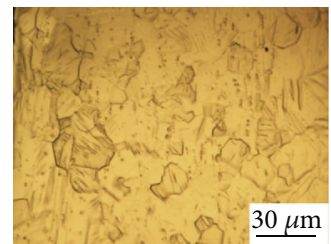

(g)

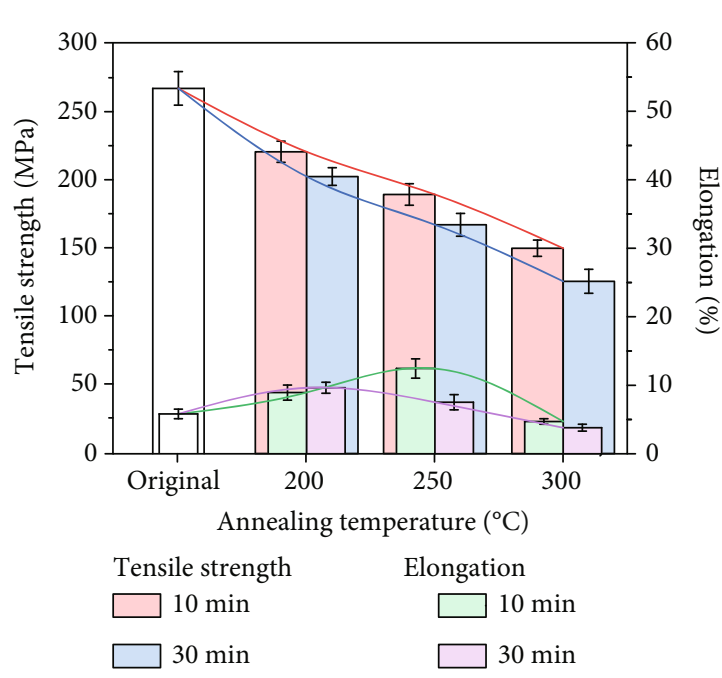

(j)

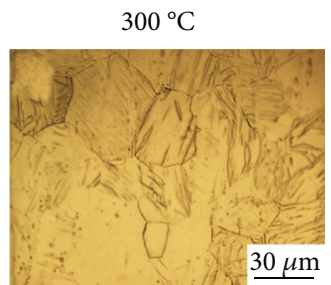

(d)

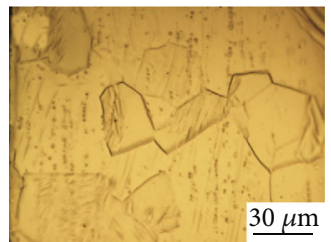

(h)

Figure 7: Microstructures and mechanical properties of $\mathrm{Zn}-0.2 \mathrm{Mg}$ wire annealed in different parameters: (a) $150^{\circ} \mathrm{C}-10 \mathrm{~min}$, (b) $200^{\circ} \mathrm{C}$ $10 \mathrm{~min}$, (c) $250^{\circ} \mathrm{C}-10 \mathrm{~min}$, (d) $300^{\circ} \mathrm{C}-10 \mathrm{~min}$, (e) $150^{\circ} \mathrm{C}-30 \mathrm{~min}$, (f) $200^{\circ} \mathrm{C}-30 \mathrm{~min}$, (g) $250^{\circ} \mathrm{C}-30 \mathrm{~min}$, (h) $300^{\circ} \mathrm{C}-30 \mathrm{~min}$, (i) microhardness, and (j) tensile strength and elongation.

UTS and YS. The as-cast Zn has the lowest UTS of $14 \mathrm{MPa}$ while UTS of Zn-0.2 Mg reaches the maximum of $74 \mathrm{MPa}$. The strengthening effect results from grain refinement and the formation of second phases. Figures $4(\mathrm{~b})$ and $4(\mathrm{c})$ show the mechanical properties of pure $\mathrm{Zn}$ and $\mathrm{Zn}-\mathrm{xMg}$ alloys after the deformation process. After hot extrusion, both the grain refinement and dispersed $\mathrm{Mg}_{2} \mathrm{Zn}_{11}$ in $\mathrm{Zn}$-xMg alloys contribute to an enhancement in mechanical properties, which UTS reaches $117 \pm 8.9 \mathrm{MPa}$ for pure $\mathrm{Zn}$ and $174 \pm$ 7.7 MPa for $\mathrm{Zn}-0.2 \mathrm{Mg}$. The as-extruded $\mathrm{Zn}$ alloys have a grain size $>20 \mu \mathrm{m}$, in which grain boundary sliding can be activated. Thus, the as-extruded $\mathrm{Zn}$ alloys have limited ELs below $10 \%$. As shown in Figure 4(c), there is an increasing trend in UTSs and YSs of as-drawn Zn and Zn alloys. UTSs increase with $\mathrm{Mg}$ addition: the as-drawn Zn wire has UTS of $130 \mathrm{MPa}$, and $\mathrm{Zn}-0.2 \mathrm{Mg}$ wire shows an UTS of $270 \mathrm{MPa}$. By contrast, it is found that there are no changes in ELs of $\mathrm{Zn}$ $\mathrm{xMg}$ alloys but an obvious increase in EL of pure $\mathrm{Zn}$ to
$18.2 \%$, which is attributed to the dynamic recrystallization at RT. Liu et al. reported the extraordinary plasticity of ascast pure zinc is attributed to dynamic recrystallization [31]. However, the dynamic recrystallization might be restrained by the solid solution and second phase; so, the equiaxed crystals cannot be found in the as-drawn $\mathrm{Zn}-\mathrm{xMg}$ alloys. Furthermore, the as-drawn $\mathrm{Zn}-\mathrm{xMg}$ alloy wires are heat-treated at $250^{\circ} \mathrm{C}$ for $10 \mathrm{~min}$, and the as-annealed $\mathrm{Zn}$ $\mathrm{xMg}$ alloy wires exhibit comprehensive mechanical properties with combined strength and plasticity.

Moreover, the work also investigated the effect of annealing on microstructure and mechanical properties. Figure 5 exhibits the microstructures and mechanical properties of as-annealed $\mathrm{Zn}-0.02 \mathrm{Mg}$. Both, raising treatment temperature and prolonging time, coarsen microstructures regulate mechanical properties. In the recovery process at $100^{\circ} \mathrm{C}$, the hardness seems to give no obvious sign of slowing down along with a slight increase in grain size. When the 


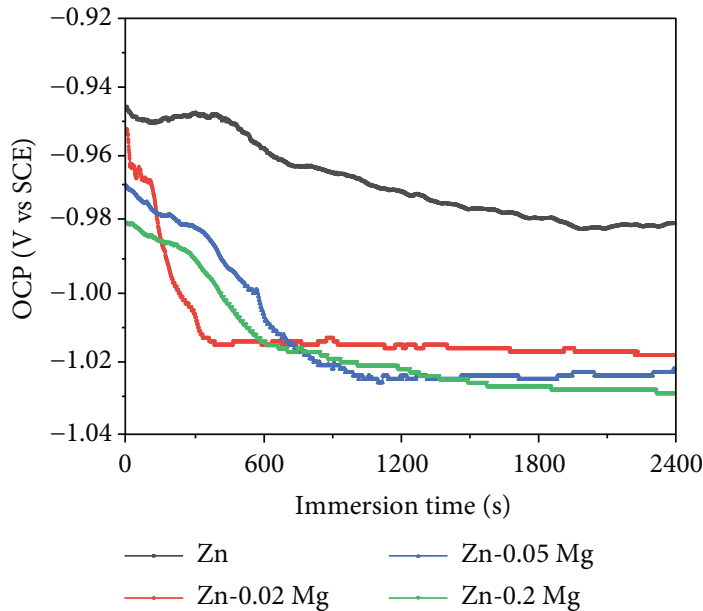

(a)

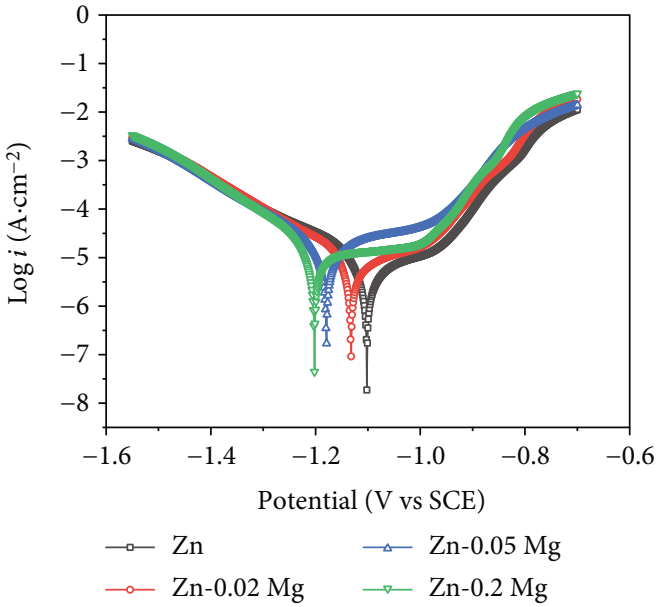

(b)

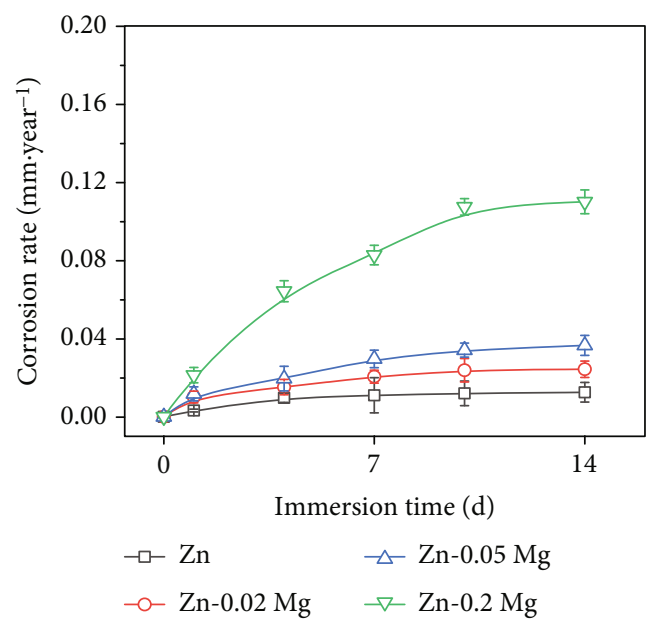

(c)

FIgure 8: Corrosion measurements: (a) OCP curves, (b) PP curve, and (c) corrosion rate measured by weight loss.

TABLE 2: Corrosion rate calculated by electrochemical methods and weight loss measurements.

\begin{tabular}{lcccrr}
\hline Alloy & Methods & Zn & Zn-0.02 mg & Zn-0.05 mg & Zn-0.2 mg \\
\hline CR $_{1}$ (mm/year) & Electrochemical methods & $0.019 \pm 0.002$ & $0.029 \pm 0.003$ & $0.040 \pm 0.005$ & $0.036 \pm 0.010$ \\
$\mathrm{CR}_{2}$ (mm/year) & Weight loss measurements & $0.010 \pm 0.001$ & $0.020 \pm 0.001$ & $0.030 \pm 0.002$ & $0.104 \pm 0.002$ \\
\hline
\end{tabular}

annealing temperature is above $100^{\circ} \mathrm{C}$, the microhardness decreases sharply with the weakness of the inherited structure and occurrence of equiaxial grains, indicating the recrystallization process. The completed recrystallization might be performed at temperature above $200^{\circ} \mathrm{C}$, in which the microhardness tends to be stable. Figure 5(j) shows the UTS and EL results of the as-annealed $\mathrm{Zn}-0.02 \mathrm{Mg}$. As the annealing temperature rises, UTS decreases in opposite to the increase of EL. Meanwhile, with annealing prolonged to $30 \mathrm{~min}$, it is obvious that UTS decrease and EL increases. However, annealed at $250^{\circ} \mathrm{C}$ for $30 \mathrm{~min}$, the excessive grain coarsening also makes damage to the improvement of EL. As mentioned above, the optimized parameter for annealing is at $250^{\circ} \mathrm{C}$ for $10 \mathrm{~min}$, and the as-annealed $\mathrm{Zn}-0.02 \mathrm{Mg}$ wire has an UTS of $172 \mathrm{MPa}$ and EL of $28.5 \%$. The short-time annealing at high temperature might complete recrystallization and retard excessive grain coarsening, leading to an increase in EL of the annealed $\mathrm{Zn}$ alloy wires.

Figures $6(\mathrm{a})-6(\mathrm{~h})$ and $7(\mathrm{a})-7(\mathrm{~h})$ display the microstructures of the annealed $\mathrm{Zn}-0.05 \mathrm{Mg}$ and $\mathrm{Zn}-0.2 \mathrm{Mg}$ alloy wires. An increase in $\mathrm{Mg}$ hinders the reversion and recrystallization, and a higher temperature is applied for annealing. The microstructure and microhardness evolution of $\mathrm{Zn}$ $0.05 \mathrm{Mg}$ and $\mathrm{Zn}-0.2 \mathrm{Mg}$ alloys are similar to that of the $\mathrm{Zn}$ $0.02 \mathrm{Mg}$ alloy. The microstructure evolution process is composed of recovery, recrystallization, and coarsening stages. Figures 6(i), 6(j), 7(i), and 7(j) display the hardness and tensile test results. By comparison, the annealing temperature has more significant effects on microstructure and mechanical properties than the treatment time. In conclusion, $\mathrm{Zn}$ - 


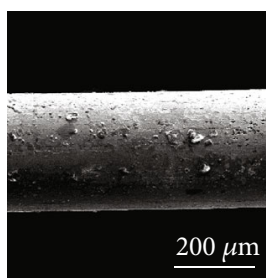

(a)

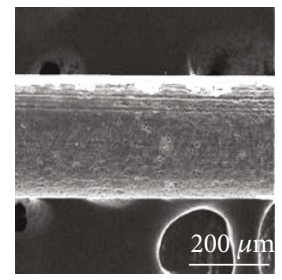

(e)

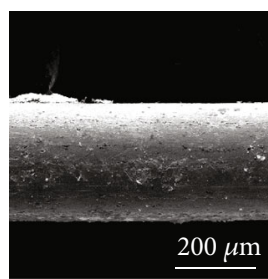

(b)

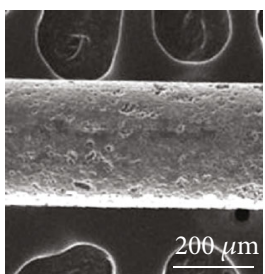

(f)

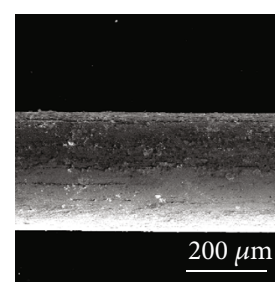

(c)

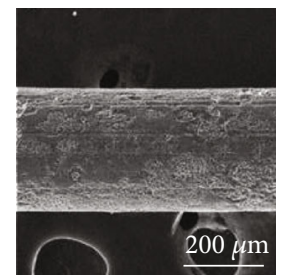

(g)

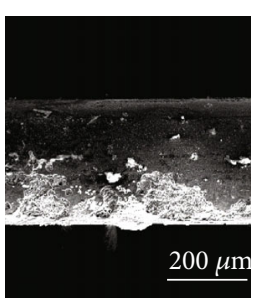

(d)

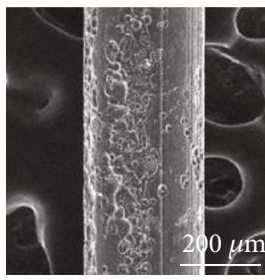

(h)

Figure 9: Morphologies of $\mathrm{Zn}-\mathrm{xMg}$ wires immersed for 7 days: (a) pure $\mathrm{Zn}$ wire, (b) Zn-0.02 Mg wire, (c) Zn-0.05 Mgwire, and (d) Zn$0.2 \mathrm{Mg}$ wire. Corrosion morphologies of $\mathrm{Zn}-\mathrm{xMg}$ wires immersed for 14 days: (e) pure Zn wire, (f) Zn-0.02 Mg wire, (g) Zn-0.05 Mgwire, and (h) Zn-0.2 Mgwire.

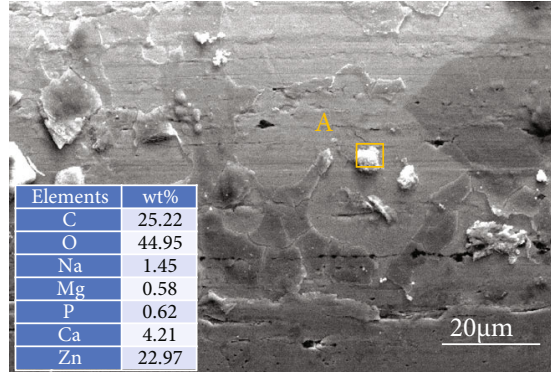

(a)

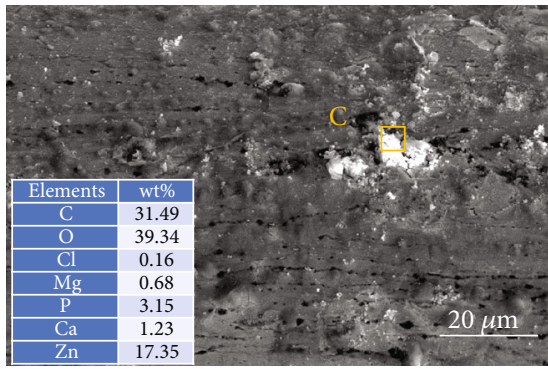

(c)

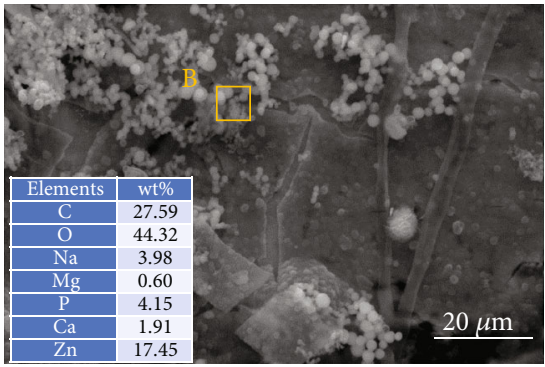

(b)

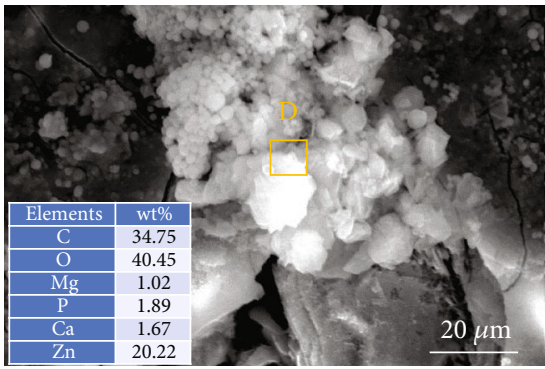

(d)

Figure 10: Morphologies and EDS of corrosion products on the surface of Zn-xMg wires immersed for 7 days: (a) pure $\mathrm{Zn}$ wire, (b) Zn$0.02 \mathrm{Mg}$ wire, (c) $\mathrm{Zn}-0.05 \mathrm{Mg}$ wire, and (d) $\mathrm{Zn}-0.2 \mathrm{Mg}$ wire.

$\mathrm{xMg}$ alloy wires have a desirable microstructure and optimized mechanical properties after annealed at $250^{\circ} \mathrm{C}$ for $10 \mathrm{~min}$. Annealed at the optimized parameter, the $\mathrm{Zn}$ $0.05 \mathrm{Mg}$ alloy wire has an UTS of $204 \mathrm{MPa}$ and EL of $16.7 \%$ while the $\mathrm{Zn}-0.2 \mathrm{Mg}$ alloy wire has an UTS of $165 \mathrm{MPa}$ and EL of $12.3 \%$. Herein, the plasticity of $\mathrm{Zn}-0.2 \mathrm{Mg}$ alloy wire was improved with limits owing to more intermediate phases.

Figure 8 exhibits the electrochemical results of colddrawn $\mathrm{Zn}$ and annealed $\mathrm{Zn}-\mathrm{xMg}$ alloy wires, and Table 2 lists the corrosion rate (CR) calculated by electrochemical methods and weight loss measurements. After the initial immersion in Hank's solution, OCP values (in Figure 8(a)) are stable to about $-0.98 \mathrm{~V}$ (vs SCE) for pure $\mathrm{Zn},-1.02 \mathrm{~V}$ (vs SCE) for Zn-0.02 Mg, $-1.02 \mathrm{~V}$ (vs SCE) for $\mathrm{Zn}-0.05 \mathrm{Mg}$, and $-1.03 \mathrm{~V}$ (vs SCE) for $\mathrm{Zn}-0.2 \mathrm{Mg}$, respectively. $\mathrm{Mg}$ addition for $\mathrm{Zn}$ alloys increases the tendency towards corrosion. In PP curves, $\mathrm{Zn}-\mathrm{xMg}$ alloy wires exhibit larger corrosion current density $\left(i_{\text {corr }}\right)$ with $\mathrm{Mg}$ addition. The $i_{\text {corr }}$ is a major evaluation criterion of corrosion rate [32]. The corrosion rate is calculated from the electrochemical results, as shown in Figure 8 (b). Zn-0.05 Mg and $\mathrm{Zn}-0.2 \mathrm{Mg}$ alloy wires display rapid degradation rates. Moreover, the long-time immersion 
tests directly reflect the degradation behavior of the $\mathrm{Zn}$ alloys after implantation. Figure 8(c) shows the corrosion rate curves based on weight loss tests. $\mathrm{Zn}-0.2 \mathrm{Mg}$ alloy wire is degraded at a relatively higher rate while pure $\mathrm{Zn}$ wire has the lowest degradation rate. The mentioned above reflects that $\mathrm{Mg}$ alloying is conducive to improving the biodegradability of $\mathrm{Zn}$ alloys for biomedical applications.

In order to further evaluate the degradation behavior, the surface morphologies of $\mathrm{Zn}$ and $\mathrm{Zn}-\mathrm{xMg}$ alloy wires after immersion are exhibited in Figures 9(a)-9(h). Few corrosion pits are found in $\mathrm{Zn}$ wires after $7 \mathrm{~d}$ and $14 \mathrm{~d}$ immersion. $\mathrm{Zn}$ $\mathrm{xMg}$ alloy wires are seriously corroded with $\mathrm{Mg}$ addition. Besides, the corrosion product morphologies are shown in Figures 10 (a)-10(d). $\mathrm{Zn}-0.2 \mathrm{Mg}$ alloy wire is covered by a mass of corrosion products, which is attributed to the rapid degradation of $\mathrm{Mg}$-rich second phases. Besides, the rapid formation of corrosion products might temporarily slow down the corrosion rate during PP measurements after the initial immersion of $30 \mathrm{~min}$. Thus, for $\mathrm{Zn}-0.2 \mathrm{Mg}$ alloy wire, the corrosion rate calculated by PP seems to mismatch with that one measured by weight loss. Based on EDS analysis, the corrosion products of $\mathrm{Zn}$ alloys in Hank's solution are composed of $\mathrm{Zn}, \mathrm{O}$, and $\mathrm{C}$ elements as well as a few $\mathrm{Mg}$, $\mathrm{Ca}$, and $\mathrm{P}$ elements, indicating that the corrosion product is composed of complex $\mathrm{Zn}$ mineral phases [33], which might be $\mathrm{ZnO}, \mathrm{Zn}_{5}\left(\mathrm{CO}_{3}\right)_{2}(\mathrm{OH})_{6}, \mathrm{Zn}_{3}\left(\mathrm{PO}_{4}\right)_{2} \cdot 4 \mathrm{H}_{2} \mathrm{O}$, and $\mathrm{Ca}-\mathrm{P}$ compounds [34]. With immersion time prolonging to $14 \mathrm{~d}$, many deeper and more intensive corrosion pits occur on $\mathrm{Zn}-\mathrm{xMg}$ alloys, especially $\mathrm{Zn}-0.2 \mathrm{Mg}$ alloys, as shown in Figures $9(\mathrm{e})-9(\mathrm{~h})$. These results are corresponding to that ones in Figure 8.

\section{Conclusions}

In this study, $\mathrm{Zn-xMg}(x=0.02,0.05,0.2 \mathrm{wt} \%)$ alloy wires were prepared and investigated for biomedical applications. For the as-cast $\mathrm{Zn}$ and $\mathrm{Zn}$-xMg alloys, $\mathrm{Mg}$ alloying led to an obvious decrease in average grain size and improves the tensile properties. Hot extrusion and cold drawing can substantially enhance the UTSs of Zn-xMg alloy and increase the ELs $(5-8 \%)$ to a limited degree. Deformation texture was formed during the production, especially for $\mathrm{Zn}$ alloys with $\mathrm{Mg}$ alloying. Annealing treatment refined the structures of $\mathrm{Zn}-\mathrm{xMg}$ alloy which further improved the plasticity but slightly decreased strength. After the optimized annealing process, $\mathrm{Zn}-0.05 \mathrm{Mg}$ had the desirable comprehensive mechanical properties with UTS and EL reaching $204 \mathrm{MPa}$ and $16.7 \%$, respectively. Moreover, based on electrochemical measurements and immersion tests, $\mathrm{Mg}$ alloying increased the degradation rates of $\mathrm{Zn}$ alloy wires in Hank's solution. The research explored $\mathrm{Zn-xMg}$ alloy fine wires for biomedical applications and investigated the effect of the preparation process on service performances of $\mathrm{Zn}-\mathrm{xMg}$ alloy fine wires.

\section{Data Availability}

The data used to support findings of this study are included within the article.

\section{Conflicts of Interest}

The authors declare that there is no conflict of interest regarding the publication of this article.

\section{Acknowledgments}

The authors thank all staff members of station BL14B1 (SSRF, China) for SR-XRD analysis. This work was supported by the National Key Research and Development Program of China (No. 2016YFC1102402), the National Natural Science Foundation of China (No. 51971062), the Science and Technology Project of Jiangsu Province (No. BE2019679), the Technological Innovation of Key Industry of Suzhou (SYG201904), and the Open Research Fund of Jiangsu Key Laboratory for Advanced Metallic Materials (AMM2021A01).

\section{References}

[1] Y. F. Zheng, X. N. Gu, and F. Witte, "Biodegradable metals," Materials Science and Engineering: R: Reports, vol. 77, pp. 134, 2014.

[2] H. F. Li, Y. F. Zheng, and L. Qin, "Progress of biodegradable metals," Progress in Natural Science: Materials International, vol. 24, no. 5, pp. 414-422, 2014.

[3] M. Peuster, C. Hesse, T. Schloo, C. Fink, P. Beerbaum, and C. von Schnakenburg, "Long-term biocompatibility of a corrodible peripheral iron stent in the porcine descending aorta," Biomaterials, vol. 27, no. 28, pp. 4955-4962, 2006.

[4] H. Hermawan, H. Alamdari, D. Mantovani, and D. Dube, "Iron-manganese: new class of metallic degradable biomaterials prepared by powder metallurgy," Powder Metallurgy, vol. 51, no. 1, pp. 38-45, 2008.

[5] C. Liu, Z. Ren, Y. D. Xu, S. Pang, X. B. Zhao, and Y. Zhao, "Biodegradable magnesium alloys developed as bone repair materials: a review," Scanning, vol. 2018, Article ID 9216314, 15 pages, 2018.

[6] X. Z. Gao, C. Y. Dai, Q. Jia et al., "In vivo corrosion behavior of biodegradable magnesium alloy by MAF treatment," Scanning, vol. 2021, Article ID 5530788, 9 pages, 2021.

[7] M. P. Staiger, A. M. Pietak, J. Huadmai, and G. Dias, "Magnesium and its alloys as orthopedic biomaterials: a review," Biomaterials, vol. 27, no. 9, pp. 1728-1734, 2006.

[8] M. Esmaily, J. E. Svensson, S. Fajardo et al., "Fundamentals and advances in magnesium alloy corrosion," Progress in Materials Science, vol. 89, pp. 92-193, 2017.

[9] X. N. Gu, Y. F. Zheng, Y. Cheng, S. P. Zhong, and T. F. Xi, "In vitro corrosion and biocompatibility of binary magnesium alloys," Biomaterials, vol. 30, no. 4, pp. 484-498, 2009.

[10] K. Chen, Y. Lu, H. Y. Tang et al., "Effect of strain on degradation behaviors of WE43, Fe and Zn wires," Acta Biomaterialia, vol. 113, pp. 627-645, 2020.

[11] G. N. Li, S. M. Zhu, J. F. Nie, Y. F. Zheng, and Z. L. Sun, "Investigating the stress corrosion cracking of a biodegradable $\mathrm{Zn}-0.8$ wt $\% \mathrm{Li}$ alloy in simulated body fluid," Bioactive Materials, vol. 6, no. 5, pp. 1468-1478, 2021.

[12] H. T. Yang, B. Jia, Z. C. Zhang et al., "Alloying design of biodegradable zinc as promising bone implants for load- bearing applications," Nature Communications, vol. 11, no. 1, p. 401, 2020. 
[13] G. N. Li, H. T. Yang, Y. F. Zheng et al., "Challenges in the use of zinc and its alloys as biodegradable metals: perspective from biomechanical compatibility," Acta Biomaterialia, vol. 97, pp. 23-45, 2019.

[14] H. Liu, H. Huang, Y. Zhang et al., "Evolution of Mg-Zn second phases during ECAP at different processing temperatures and its impact on mechanical properties of $\mathrm{Zn}-1.6 \mathrm{Mg}$ (wt.\%) alloys," Journal of Alloys and Compounds, vol. 811, article 151987, 2019.

[15] C. Chen, R. Yue, J. Zhang, H. Huang, J. L. Niu, and G. Y. Yuan, "Biodegradable $\mathrm{Zn}-1.5 \mathrm{Cu}-1.5 \mathrm{Ag}$ alloy with anti-aging ability and strain hardening behavior for cardiovascular stents," Materials Science and Engineering: C, vol. 116, article 111172, 2020.

[16] R. Yue, J. L. Niu, Y. T. Li et al., "In vitro cytocompatibility, hemocompatibility and antibacterial properties of biodegradable $\mathrm{Zn}-\mathrm{Cu}-\mathrm{Fe}$ alloys for cardiovascular stents applications," Materials Science and Engineering: C, vol. 113, article 111007, 2020.

[17] K. M. Hambidge and N. F. Krebs, "Zinc deficiency: a special challenge," The Journal of Nutrition, vol. 137, no. 4, pp. 1101-1105, 2007.

[18] P. J. Aggett and J. T. Harries, "Current status of zinc in health and disease states," Archives of Disease in Childhood, vol. 54, no. 12, pp. 909-917, 1979.

[19] Y. Liu, Y. F. Zheng, X. H. Chen et al., "Fundamental theory of biodegradable metals-definition, criteria, and design," Advanced Functional Materials, vol. 29, no. 18, article 1805402, 2019.

[20] P. K. Bowen, J. Drelich, and J. Goldman, "Zinc exhibits ideal physiological corrosion behavior for bioabsorbable stents," Advanced Materials, vol. 25, no. 18, pp. 2577-2582, 2013.

[21] D. Vojtech, J. Kubasek, J. Serak, and P. Novak, "Mechanical and corrosion properties of newly developed biodegradable Zn-based alloys for bone fixation," Acta Biomaterialia, vol. 7, no. 9, pp. 3515-3522, 2011.

[22] H. F. Li, H. T. Yang, Y. F. Zheng, F. Y. Zhou, K. J. Qiu, and $\mathrm{X}$. Wang, "Design and characterizations of novel biodegradable ternary $\mathrm{Zn}$-based alloys with IIA nutrient alloying elements $\mathrm{Mg}, \mathrm{Ca}$ and Sr," Materials \& Design, vol. 83, pp. 95102, 2015.

[23] C. Xiao, L. Q. Wang, Y. P. Ren et al., "Indirectly extruded biodegradable $\mathrm{Zn}-0.05 \mathrm{wt} \% \mathrm{Mg}$ alloy with improved strength and ductility: In vitro and in vivo studies," Journal of Materials Science and Technology, vol. 34, no. 9, pp. 1618-1627, 2018.

[24] H. F. Li, X. H. Xie, Y. F. Zheng et al., "Development of biodegradable $\mathrm{Zn}$-1X binary alloys with nutrient alloying elements Mg, Ca and Sr," Scientific Reports, vol. 5, no. 1, article 10719, 2015.

[25] J. M. Seitz, M. Durisin, J. Goldman, and J. W. Drelich, "Recent advances in biodegradable metals for medical sutures: a critical review," Advanced Healthcare Materials, vol. 4, no. 13, pp. 1915-1936, 2015.

[26] J. Bai, L. L. Yin, Y. Lu et al., "Preparation, microstructure and degradation performance of biomedical magnesium alloy fine wires," Progress in Natural Science: Materials International, vol. 24, no. 5, pp. 523-530, 2014.

[27] H. Guo, R. H. Cao, Y. F. Zheng, J. Bai, F. Xue, and C. L. Chu, "Diameter-dependent_in vitro__performance of biodegradable pure zinc wires for suture application," Journal of Materials Science and Technology, vol. 35, no. 8, pp. 1662-1670, 2019.
[28] Y. Okamura, N. Hinata, T. Hoshiba et al., "Development of bioabsorbable zinc-magnesium alloy wire and validation of its application to urinary tract surgeries," World Journal of Urology, vol. 39, no. 1, pp. 201-208, 2021.

[29] H. Abrams, "Grain size measurement by the intercept method," Metallography, vol. 4, no. 1, pp. 59-78, 1971.

[30] M. C. Zhao, P. Schmutz, S. Brunner, M. Liu, G. L. Song, and A. Atrens, "An exploratory study of the corrosion of Mg alloys during interrupted salt spray testing," Corrosion Science, vol. 51, no. 6, pp. 1277-1292, 2009.

[31] S. Y. Liu, D. Kent, H. Y. Zhan, N. Doan, M. Dargusch, and G. Wang, "Dynamic recrystallization of pure zinc during high strain-rate compression at ambient temperature," Materials Science and Engineering: A, vol. 784, article 139325, 2020.

[32] Q. S. Dong, X. X. Zhou, Y. J. Feng et al., "Insights into selfhealing behavior and mechanism of dicalcium phosphate dihydrate coating on biomedical Mg," Bioactive Materials, vol. 6, no. 1, pp. 158-168, 2021.

[33] C. García-Mintegui, L. C. Córdoba, J. Buxadera-Palomero et al., " $\mathrm{Zn}-\mathrm{Mg}$ and $\mathrm{Zn}-\mathrm{Cu}$ alloys for stenting applications: From nanoscale mechanical characterization to_in vitro_degradation and biocompatibility," Bioactive Materials, vol. 6, no. 12, pp. 4430-4446, 2021.

[34] X. Liu, W. Yuan, D. Shen, Y. Cheng, D. Chen, and Y. Zheng, "Exploring the biodegradation of pure $\mathrm{Zn}$ under simulated inflammatory condition," Corrosion Science, vol. 189, article 109606, 2021. 